\title{
PROSES PENGINSTANAN AGLOMERASI KERING DAN PENGARUHNYA TERHADAP SIFAT FISIKO KIMIA KOPI BUBUK ROBUSTA (Coffea robusta Lindl. Ex De Will)
}

\section{THE INSTANT COFFEE PROCESSING OF ROBUSTA GROUND COFFEE (COFFEA ROBUSTA LINDL. EX DE WILL) AND ITS INFLUENCE ON PHYSICO CHEMICAL CARACTERISTICS}

\author{
Patoni A. Gafar \\ Balai Riset dan Standardisasi Industri Palembang \\ JI. Perindustrian II No. 12 Sukarame KM 9 Palembang \\ e-mail : patoni ag@yahoo.com
}

\begin{abstract}
Abstrak
Penelitian ini bertujuan untuk memperoleh data dan informasi tentang paket teknologi pengolahan produk kopi berbahan baku robusta dengan cepatnya waktu kristalisasi terkait dengan karakteristik kopi instan yang dihasilkan termasuk penurunan kadar kafein. Penggunaan kopi robusta sebagai bahan baku dalam proses pembuatan kopi instan merupakan salah satu alternatif dalam melakukan proses hilirisisasi kopi terutama bagi industri kecil dan menengah dengan kualitas yang cukup baik. Di samping itu karena kopi robusta memiliki kandungan kafein yang lebih tinggi dibandingkan dengan kopi arabika, maka penginstanan merupakan salah satu cara untuk menurunkan kadar kafein. Perlakuan yang digunakan pada eksperimen berupa lama proses kristalisasi dengan aglomerasi/pengeringan dilakukan dengan dua cara yaitu pengeringan lambat $\left(T_{1}\right)$ dan cepat $\left(T_{2}\right)$, sebagai kontrol digunakan kopi bubuk tanpa penginstanan $\left(T_{0}\right)$. Pengujian parameter dilakukan terhadap rendemen, kadar kafein, kadar air, kadar abu, serta kelarutan dan keadaan warna dan citarasa. Hasil penelitian menunjukkan bahwa kadar rendemen, kadar kafein, kadar air, dan kadar abu kopi bubuk masing-masing adalah 84,6\%, 2,14\%, $2,15 \%$, dan 4,8\%. Sedangkan untuk kopi instan dengan kristalisasi lambat masing-masing 25,38\%, $0,71 \%, 2,72 \%$ dan $1,15 \%$, serta untuk kopi instan kristalisasi cepat berturut-turut $25,38 \%, 0,65 \% .2,72 \%$ dan $1,15 \%$. Untuk kopi instan, baik dengan kristalisasi lambat maupun cepat, dapat larut dalam air panas/dingin serta keadaan normal. Dengan demikian dari aspek kadar air, kadar abu, serta kelarutan dan keadaan hasilnya sesuai dengan SNI 2983:2014 tentang kopi instan.
\end{abstract}

Kata kunci : fisiko kimia, kopi instan, kristalisasi, penginstanan

\begin{abstract}
The purpose of this research was to obtain the data and information about processing technology of coffee product of robusta coffee in case of apprpropriate crystallization process on instant coffee. The use of robusta coffee as raw material in instant coffee producing was an alternative in making its good down stream product for small and medium scale of industry. Robusta coffee has a higher content of caffeine than of Arabica coffee. The treatments used were two ways of crystallization process by dry aglomeration, slow process $\left(T_{1}\right)$ and quick process $\left(T_{2}\right)$, as the control used ground coffee without instantly process $\left(T_{0}\right)$. The parameters tested were yield, caffeine content, moisture content, ash content of ground coffee were $84.6 \%, 2.14 \%, 2.15 \%$ and $4.8 \%$ each; whereas for instant coffee by slow crystallization were $25,38 \%, 0,71 \%, 2,72 \%$ and $1,15 \%$ each, and also for instant coffee by fast crystallization were $25,38 \%, 0,65 \% .2,72 \%$ dan $1,15 \%$ each. For instant coffee which crystallization slowly and quickly had good solubility and physical condition. Those were the resons that the instant coffee fulfill the SNI 2983:2014 when they were observed of moisture, ash, solubility and physical condition.
\end{abstract}

Keywords : physico chemical, instant coffee, crystalization, processing

\section{PENDAHULUAN}

Sebagai negara penghasil kopi (Coffea sp) terbesar keempat di dunia setelah Brazil, Vietnam, dan Colombia. Indonesia menyumbang sekitar $6,42 \%$ dari total produksi kopi dunia. Dari total produksi yang dapat mencapai 639.000 ton tahun 2017 , sekitar $79,4 \%$ diekspor sedangkan sisanya $(20,6 \%)$ untuk memenuhi kebutuhan dalam negeri (Kemenperin, 2017). 
Beberapa sentra produksi kopi robusta di Indonesia antara lain Sumatera Selatan (Muara Enim, Lahat, Ogan Komering Ulu, OKU Selatan, OKU Timur, Pagar Alam dan Empat Lawang), Lampung (Lampung Barat, Lampung Selatan, Lampung Tengah dan Tanggamus), Nusa Tenggara Timur (Flores), dan Jawa Tengah (Temanggung). Kopi merupakan komoditas penting dan biasanya dipasarkan dalam bentuk kopi beras (Najiyati, 2002). Bila dilakukan pengujian berdasarkan SNI 01-29072008 tentang biji kopi, permasalahan pada pengembangan biji kopi rakyat adalah mutu biji kopi yang dihasilkan masih rendah, yaitu berkisar antara tingkat mutu III dan IV. Salah satu kopi robusta produksi Sumatera Selatan, yaitu Kopi Robusta Semende, mempunyai kelebihan tersendiri karena telah diakui keunggulannya yang terbukti dengan telah diperolehnya sertifikat berupa kopi robusta Indikasi Geografis (IG) dari Kementerian Hukum dan HAM RI.

Suatu produk hilir kopi yang sifatnya mudah larut dengan air (soluble) serta tidak manghasilkan ampas adalah kopi instan. Pembuatan kopi instan pada prinsipnya adalah pembuatan kopi yang manggunakan proses pemekatan seduhan (ekstrak) kopi yang selanjutnya dikeringkan . Bagian kopi bubuk yang dapat diekstraksi merupakan bagian yang dapat larut dalam air/soluble (Gafar, 2017).

Mulato dan Suharyanto (2012) melaporkan bahwa kurang lebih 20\% produksi kopi dunia dikonversi menjadi bubuk kopi instan, kopi jenis ini digemari oleh $70 \%$ masyarakat AsiaAustralia dan 60\% masyarakat Eropa bagian Timur.

Aglomerasi merupakan suatu cara dalam proses kristalisasi. Kristalisasi merupakan istilah yang menjelaskan beberapa fenomena yang berbeda yang berhubungan dengan pembentukan struktur matriks kristal. Aglomerasi merupakan suatu proses penggabungan partikel-partikel padat bahan yang berukuran kecil menjadi partikel-partikel padat yang lebih besar. Aglomerasi bertujuan untuk memberikan gaya ikat (adhesi) partikel-partikel padat yang berukuran kecil untuk membentuk partikel padat yang berukuran lebih besar (Schuchman, 1995).

Penelitian ini bertujuan untuk memperoleh data dan informasi tentang paket teknologi pengolahan produk kopi berbahan baku robusta dengan cepatnya waktu kristalisasi/aglomerasi terkait dengan karakteristik kopi instan yang dihasilkan.

\section{BAHAN DAN METODE}

\section{Bahan dan Alat}

Bahan-bahan yang digunakan meliputi kopi biji/beras dari varietas robusta yang berasal dari perkebunan rakyat di Sumatera Selatan, gula pasir dan air. Peralatan yang digunakan berupa timbangan, mesin sangrai/roaster, kristalisator/ dry aglomerator, penggiling/ grinder, saringan, sealer, dan peralatan pendukung lainnya.

\section{Metode Penelitian \\ Rancangan Percobaan}

Rancangan yang digunakan pada penelitian ini adalah Rancangan Acak Lengkap (RAL) faktor tunggal dengan 3 kali ulangan (ul.1, ul.2 dan ul.3). Faktor yang diterapkan berupa teknik penginstanan $(\mathrm{T})$, yaitu :

- $\mathrm{T}_{0}=$ tanpa penginstanan (kontrol)

- $\mathrm{T}_{1}=$ penginstanan lambat

- $T_{2}=$ penginstanan cepat

Model matematis dari rancangan yang digunakan sebagai berikut :

Yir $=\mu+$ Tir $+€$ ir

dimana :

Yir = respons perlakuan ke $\mathrm{i}$ pada ulangan ke $\mathrm{r}$

$\mu=$ nilai tengah umum

Tir = pengaruh perlakuan ke i pada ulangan ke $r$

$€$ ir = pengaruh galat dari perlakuan ke i dan ulangan ke $r$. 


\section{Prosedur Penginstanan Kopi}

Proses produksi kopi instan dibagi menjadi 3 tahapan utama, yaitu penyiapan bahan baku, ekstraksi dan dehidrasi. Secara lengkap prosedur penginstanan kopi adalah sebagai berikut.

1. Penimbangan dan Pengukuran Penimbangan dilakukan terhadap kopi biji/beras sebagai basis untuk pengujian rendemen, baik kopi bubuk maupun kopi instan; demikian juga dengan penimbangan gula pasir dilakukan untuk menyesuaikan dengan volume ekstrak (gula-ekstrak 1 banding 2) yang akan dikeringkan/dikristalkan.

Pengukuran volume dilakukan terhadap air penyeduh dengan perbandingan kopi bubuk banding air sebagai 1 banding 4 .

2. Penyortiran

Penyortiran dilakukan terhadap kopi biji untuk memisahkan bahan asing atau material non kopi.

3. Pencucian

Pencucian dilakukan terhadap kopi biji dengan menggunakan air bersih, dengan maksud untuk membersihkan kotoran halus seperti debu dan jamur.

4. Penirisan

Kopi biji yang telah dicuci ditiriskan sampai kering udara.

5. Penyangraian

Penyangraian dilakukan pada suhu sekitar $180^{\circ} \mathrm{C}$ dengan waktu sekitar 90 menit.

6. Penggilingan

Penggilingan dilakukan dengan mesin grinder dengan kehalusan saringan 80 mesh.

7. Ekstraksi

Ekstraksi dilakukan dengan menggunakan air panas/mendidih untuk memperoleh ekstrak dari kopi bubuk dengan tahapan kerja sebagai berikut :

a. Timbang kopi bubuk

b. Panaskan air dengan volume 4 kali berat kopi bubuk

c. Setelah air mendidih masukkan kopi bubuk

d. Aduk seduhan/campuran kopi dan air sekitar 30 menit, dengan api kecil, kemudian diangkat

e. Setelah diangkat, endapkan agar sari terpisah dari ampas

f. Saring seduhan dengan saringan kasar, dilanjutkan dengan saringan halus (100 mesh)

8. Kristalisasi

Ambil filtrat sebanyak 2 liter, kemudian masukkan ke dalam kristalisator/ aglomerator. Kristalisasi mula-mula dilakukan pada suhu $100{ }^{\circ} \mathrm{C}$, kemudian diturunkan menjadi $70{ }^{\circ} \mathrm{C}$, terakhir api/pemanas dimatikan. Pada proses penginstanan lambat proses kristalisasi berlangsung sekitar 60 menit, sedangkan proses cepat proses kristalisasi hanya berlangsung 40 menit, dilakukan dengan cara mengatur besarnya nyala api.

9. Penggilingan

Setelah kristal kopi diangkat/dipanen lalu dikeringkah dengan cara diangin-anginkan, kemudian dilakukan penggilingan pada kehalusan 60 mesh.

\section{Peubah yang Diamati}

Peubah terikat yang diamati dalam penelitian ini meliputi parameter rendemen, kadar kafein, kadar air, kadar abu, serta kelarutan dan keadaan. 


\section{HASIL DAN PEMBAHASAN}

\section{Rendemen}

Rendemen kopi setelah diinstankan menggambarkan banyaknya komponen terlarut dalam kopi bubuk pada proses ekstraksi. Bila pada proses pembuatan kopi bubuk mendapatkan rendemen sekitar 75,2$84,6 \%$, maka dengan proses penginstanan rendemen rata-rata didapatkan berkisar antara 22,56$25,38 \%$. Histogram pengaruh penginstanan terhadap rendemen kopi bubuk dapat dilihat pada Gambar 1 .

Kopi instan diperoleh melalui proses ekstraksi senyawa terlarut dengan cara penyeduhan (brewing). Proses ini tidak mengakibatkan perubahan kimia, dan oleh karena itu tidak menghasilkan pembentukan senyawa baru dan tergantung sepenuhnya pada sifat kelarutan masing-masing senyawa dalam pelarut (air).

Penyeduhan bubuk kopi dengan air mendidih pada kondisi tekanan normal (1 atm) hanya menghasilkan proporsi padatan terlarut maksimal $30 \%$. Sedangkan sisanya $70 \%$ padatan tidak dapat dilarutkan oleh air dan tinggal sebagai ampas (Mulato dan Suharyanto, 2012).

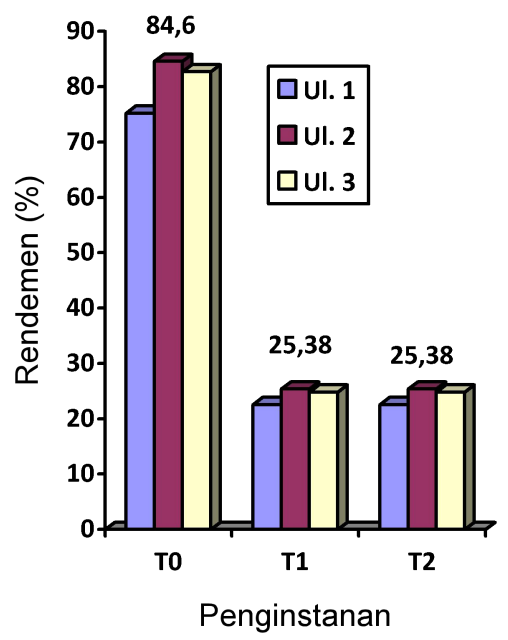

Gambar 1. Pengaruh penginstanan terhadap rendemen kopi bubuk

\section{Kadar Kafein}

Senyawa kafein dapat larut dalam air dan monosakarida sangat mudah larut dalam air. Menurut Mulato dan Suharyanto (2012) banyak jenis monosakarida yang terdapat dalam kopi, yaitu glukosa, galaktosa, rhamosa, xilosa, dan arabinosa. Budiman et al. (2010) menyatakan bahwa kopi robusta mengandung bahan kimia yang bermanfaat seperti kafein, glukosa, trigoneline, teofilina, protein, mineral, tannin, asam klorogenat dan komponen volatil.

Proses penginstanan kopi dilakukan dalam tiga tahapan utama. Ketiga tahapan utama itu meliputi penyiapan bahan baku, ekstraksi dan dehidrasi. Ketiga proses tersebut dilakukan dengan cara yang sama untuk setiap perlakuan, proses yang berbeda adalah berupa waktu atau lamanya kristalisasi. Pada penyiapan bahan baku proses yang dominan untuk membentuk karakteristik produk kopi adalah penyangraian (roasting). Penyangraian merupakan proses pemanasan suhu tinggi terhadap kopi biji selama periode waktu tertentu. Pamanasan berlangsung sekitar 200 ${ }^{\circ} \mathrm{C}$ selama kurang lebih 40 menit tergantung dari jumlah dan kondisi awal kopi biji serta tingkat sangrai yang dituju (Mulato dan Suharyanto, 2012).

Pada proses penyangraian, kafein sedikit mengalami sublimasi, yaitu pada penyangraian gelap (dark roast) $205^{\circ} \mathrm{C}$, hal ini disebabkan oleh kafein yang mempunyai sifat tahan panas sampai suhu $315{ }^{\circ} \mathrm{C}$. Di samping itu teknik kristalisasi dan pengeringan akan sangat berpengaruh terhadap mutu kopi instan yang dihasilkan, karena berkaitan dengan jenis dan jumlah senyawa volatil yang diuapkan.

Burnham (2001) menyatakan bahwa kafein merupakan senyawa berbentuk kristal, yang penyusun utamanya berupa senyawa turunan protein disebut purin xantin. Sedangkan Arwangga et al. (2016) 
menyebutkan bahwa kafein adalah salah satu jenis alkaloid yang banyak terdapat pada biji kopi, kadar kafein pada kopi mentah sebesar 1,28 \pm $0,13 \%$ dengan kadar air $1 \%$.

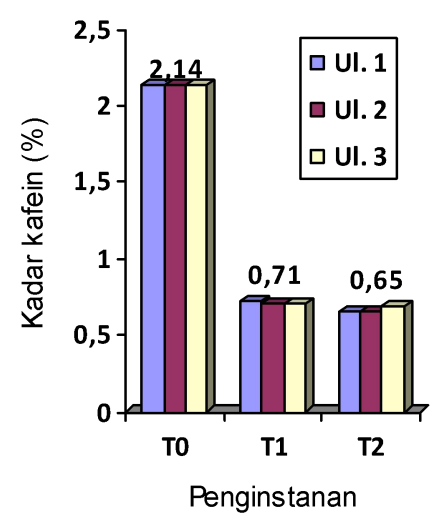

Gambar 2. Pengaruh penginstanan terhadap kadar kafein kopi bubuk

Dari Gambar 2 terlihat bahwa kadar kafein kopi bubuk (kontrol) lebih tinggi daripada kopi instan. Hal ini disebabkan oleh adanya kandungan senyawa lain yang lebih dalam kopi bubuk dibandingkan dengan kopi instan (Arwangga et al., 2016).

\section{Kadar Air}

Hasil penelitian menunjukkan bahwa kadar air kopi instan sebesar $2,72 \%$, lebih tinggi dibandingkan dengan kopi bubuk non instan (kontrol) yang sebesar $2,15 \%$.

Kadar air merupakan persentase kandungan air bahan yang biasanya dinyatakan secara berat basah (wet basis) atau berdasarkan berat kering (dry basis). Dalam penelitian ini dihitung secara wet basis.

Kadar air pada kopi sangat berpengaruh pada pertumbuhan mikroorganisme, khususnya jamur, tetapi kadar air di atas masih jauh lebih kecil dari kondisi optimum untuk pertumbuhan jamur okratoksin. Yani (2007) melaporkan bahwa produksi okratoksin akan terjadi pada kadar air di atas $13-16 \%$.

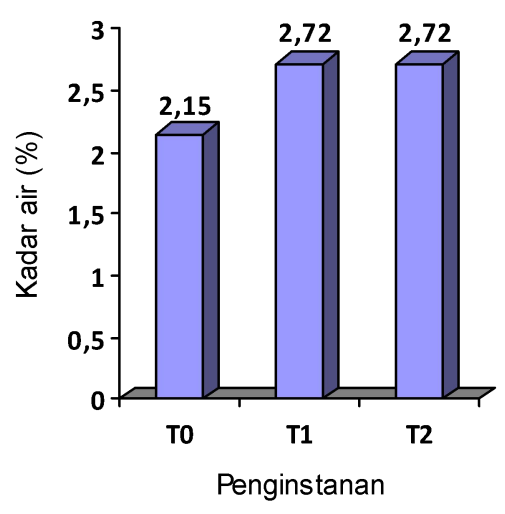

Gambar 3. Pengaruh penginstanan terhadap kadar air rata-rata kopi bubuk

Kandungan air dalam kopi instan yang dihasilkan terdapat dalam dua bentuk yaitu air terikat dan air bebas.

Air mempunyai kapasitas panas paling tinggi dan suhu didih paling rendah di antara senyawa yang terdapat pada kopi (Mulato dan Suharyanto, 2012).

Menurut deMan (1997) air dalam bahan pangan terdiri dari dua bentuk yaitu air terikat dan air bebas, air terikat juga dalam dua bentuk yaitu air yang terikat secara fisik dan terikat secara kimia. Kandungan air yang terukur pada pengujian adalah air bebas dan air yang terikat secara fisik.

Tingginya kadar air pada kopi instan akan memudahkan bakteri berkembang biak sehingga memungkinkan bahan tidak awet.

Persentase kandungan air suatu bahan dinyatakan berdasarkan berat basah (wet basis/wb) atau berdasarkan berat kering (dry basis/db). Berdasarkan berat basah kadar air mempunyai batas maksimum teoritis sebesar 100 persen, sedangkan berdasarkan berat kering kadar air dapat lebih dari 100 persen (Syarif dan Halid, 1993).

\section{Kadar Abu}

Abu dalam kopi bubuk merupakan komponen yang tidak terbakar pada pembakaran di dalam furnace pada suhu $800^{\circ} \mathrm{C}$. Komponen 
tersebut dapat berasal dari mineral yang terdapat secara alami seperti kalium, kalsium dan magnesium (Mulato dan Suharyanto, 2012), disamping itu juga mungkin terdapat berbagai zat asing yang merupakan kontaminan selama penanganan.

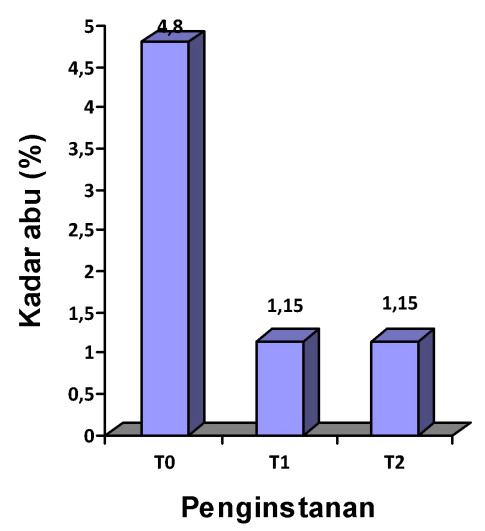

Gambar 4. Pengaruh penginstanan terhadap kadar abu rata-rata kopi bubuk

\section{Kelarutan}

Kelarutan kopi instan yang dihasilkan dalam penelitian ini adalah normal, dalam arti mempunyai kelarutan yang baik dalam air dingin dan air panas. Hal ini sesuai dengan standar kopi instan (SNI 2983:2014, tentang Kopi Instan). Kelarutan yang baik dari kopi instan tersebut disebabkan karena hanya zat yang larut dalam pelarut (dalam hal ini air) yang terekstrak. Mulyanto dan Suharyanto (2012) menyatakan bahwa dalam seduhan kopi ideal zat terlarut sebanyak 18 sampai $22 \%$. Di samping itu Yulisa et al (2013) menyatakan bahwa salah satu faktor yang menyebabkan kopi instan banyak diminati karena tidak berampas (praktis dapat larut), sedangkan Satyajaya et al (2014) menyatakan bahwa atribut kecepatan larut termasuk salah satu atribut yang penting bagi kopi instan.

\section{Keadaan}

Kopi biji secara alami mengandung prekursor aroma dan rasa yang tidak aktif hampir 250 jenis. Dengan proses penyangraian prekursor menjadi aktif dan menimbulkan senyawa-senyawa aktif pembentuk aroma dan cita rasa khas kopi (Mulato dan Suharyanto, 2012). Perubahan fisik dan kimiawi pada kopi berlangsung selama pemanasan pada proses sangrai. Perubahan fisik meliputi warna, volume dan densiti. Kombinasi suhu dan waktu pada proses penyangraian merupakan faktor penentu kesempurnaan pembentukan keadaan produk kopi seperti warna dan citarasa. Kombinasi kedua faktor tersebut dipilih sesuai dengan kesukaan konsumen. Pembentukan warna dan citarasa tersebut disebabkan oleh keberadaan senyawa asam klorogenat.

Menurut Mulato dan Suharyanto (2012), asam klorogenat terdapat dalam jumlah besar dalam kopi biji, yang selama penyangraian akan bersintesa dengan protein dan senyawa polifenol membentuk melanoidin. Melanoidin memberikan kontribusi dalam pembentukan warna dan citarasa dalam seduhan. Sedangkan sisa asam klorogenat berkontribusi terhadap sensasi rasa pahit dalam kopi.

Salah satu komponen yang berkontribusi dalam aroma adalah minyak kopi. Aziz et al. (2009) menyatakan bahwa mibyak kopi adalah salah satu produk yang berfungsi dalam armatisasi, yang terkandung $10-15 \%$ dalam biji kopi. Selanjutnya disebutkan bahwa senyawa tersebut tersusun dari kafein, asam palmitic, asam lenoleat, asam stearic dan lain-lain.

\section{KESIMPULAN}

Kopi robusta bila
proses dilakukan
menghasilkan kenginstanan $r$ akan
dengan sifat fisiko kimia tertentu.


Robusta memiliki kandungan kafein yang cukup tinggi, bila dilakukan proses penginstanan seperti pada penelitian ini akan menurunkan kadar kafein cukup signifikan. Penurunan kadar kefein ditentukan pula oleh lamanya kristalisasi/pengeringan (proses aglomerasi).

Dari hasil pengujian parameter yang dilakukan terhadap rendemen, kadar kafein, kadar abu, kadar air, kelarutan dan keadaan hasilnya sesuai dengan SNI 2983:2014. Rendemen kopi instan yang dihasilkan sebesar $24 \%$, dengan kadar kafein rata-rata $0,70 \%$ serta kadar air dan abu masingmasing $2,72 \%$ dan $1,15 \%$. Secara visual hasil pengamatan warna antara coklat sampai hitam kecoklatan dengan bau dan rasa normal.

\section{SARAN}

Penelitian dan pengembangan produk hilir kopi berbasis kopi robusta dalam bentuk kopi instan masih perlu dikembangkan lebih lanjut menjadi produk-produk dengan varian yang lebih inovatif. Hasil penelitian dapat diterapkan dengan beberapa penyesuaian.

\section{UCAPAN TERIMA KASIH}

Penulis banyak mengucapkan terima kasih kepada Kepala Baristand Industri Palembang, serta pihak-pihak lain yang tidak dapat disebutkan satu persatu atas bantuan dan dukungannya sehingga dapat terlaksananya penelitian sampai tersusunnya tulisan ini.

\section{DAFTAR PUSTAKA}

Arwangga, A.F., I.A.R.A. Asih dan I.W. Sudiarta, (2016). Analisis kandungan kafein pada kopi di Desa Sesaot Narmada menggunakan spektrofotometer UV-Vis. Jurnal Kimia 10 (1):110-114.

Aziz, T., R. Cindo K.N. dan A. Fresca., (2009). Pengaruh pelarut heksana dan etanol, volume pelarut, dan waktu ekstraksi terhadap hasil ekstraksi minyak kopi. Jurnal Teknik Kimia 16(1):1-8.

Budiman, H., F. Rahmawati dan F. Sanjaya, (2010). Isolasi dan Identifikasi Alkaloid pada Kopi Robusta (Coffea robusta Lindl. Ex De Will) Dengan Cara Kromatografi Lapis Tipis. CERATA Journal of Pharmacy Sience 1 (1) : 54-64

Burnham, T.A., (2001). Drug Fact and Comparison, St. Louis: A Walters Kluwers Company, USA.

DeMan, J.M., (1997). Kimia Makanan. Penerjemah Kosasih Padma-winata (Prof. Dr.). Penerbit ITB, Bandung.

Gafar, P.A., (2017). Pengembangan produk kopi instan robusta (Coffea robusta) dengan teknik aglomerasi kering. Jurnal Hasil Penelitian Industri 6(1):48-58

Mulato, S. dan E. Suharyanto, (2012). Kopi, Seduhan \& Kesehatan. Pusat Penelitian Kopi dan Kakao Indonesia, Jember. 257 hal.

Mulato, S., S. Widyotomo dan E. Suharyanto, (2014). Pengolahan Produk Primer dan Sekunder Kopi. Pusat Penelitian Kopi dan Kakao Indonesia, Jember. 94 hal.

Najiyati, S. dan Danarti, (2006). Kopi, Budi Daya dan Penanganan Pascapanen. Penebar Swadaya, Jakarta.

Satyajaya, W., Rangga, A., Nurainy, F., dan Rasyid, H. A., (2014). Jurnal Teknologi Industri dan Hasil Pertanian 19(2):297-306.

Syarief, R. dan H. Halid., (1993). Teknologi Penyimpanan Pangan. Arcan, Jakarta.

Schuchman, H., (1995). Production of Instant Food by Jet Aglomeration. Food Control, 6: 95-100.

Yulisa, L., Indriani, Y. dan Situmorang, S., (2013). Perilaku konsumsi mahasiswa Universitas Lampung terhadap kopi bubuk instan siap saji. JIIA 1(4):60-69.

Yani, A., (2007). Cendawan penghasil okratoksin pada kopi dan cara pencegahannya. Buletin Teknologi Pasca Panen Pertanian 3 hal. 9-15. 